\title{
The Contribution of Muslims and Islamic Concepts: Rethinking and Establishing the Actual Origin of Concepts and Thought in Psychology
}

\author{
Ajmal Majeed $^{1 *}$, Jabir K.P ${ }^{2}$
}

\section{ABSTRACT}

The paper deals with contribution of Muslim philosophers, scholars, scientists and psychologists for psychology in the early development period of psychology. One of the major aim of this paper is to re-evaluate the real and factual origin of concepts about the treatments, theories, psycho-therapies, meditation etc. Today the western countries are ruling over the psychology development. The paper explains and establishes the argument that the Concepts and theories are formed with the contribution of Muslim thoughts and ideas. Islamic approaches and interpretation play a role in the advancement of psychology. The paper focuses on several Muslim scholars like Imam Ghazali, Ashraf Ali Yhanvi, Muhammad ibn Zakariya al-Razi, AbuAli al-Husayn ibn Abdalah ibn-Sina,etc. whose contributions are not mentioned in any academic discussion or textbooks of psychology or related publication. So the paper will be a thoughtful work for the psychologists to rethink about the contribution and the role of Islam and Muslims in psychology. Prophet Muhammed (pbuh) is one of the best person who lived in this world to lead the humans toward well- being in all perspectives of life. The paper concludes with the argument that the Islamic concepts and Muslim scholars have a great role in the advancement of psychology.

Keywords: Islam, Muslim psychologist, Islamic contribution, Ghazali, Prophet Muhammed, Ibn Sina

“The Muslim believes in One God, who is all-powerful and has no partner; believes in his messengers, sent to mankind for their guidance from the beginning of time; believes that Muhammad ${ }^{\text {[Five Pillar] }}$ closed the cycle of messengers and that there can be no further revelation of the divine Law after him; believes that the Quran is the Word of God, unaltered and unalterable,

\footnotetext{
${ }^{1}$ Research Scholar, Psychology, Aligarh Muslim University, Aligarh, U.P, India

${ }^{2}$ Research Scholar, Psychology, Aligarh Muslim University, Aligarh, U.P, India

*Responding Author

Received: March 5, 2017; Revision Received: March 28, 2017; Accepted: March 30, 2017

(C) 2017 Majeed A, Jabir K; licensee IJIP. This is an Open Access Research distributed under the terms of the Creative Commons Attribution License (www.creativecommons.org/licenses/by/2.0), which permits unrestricted use, distribution, and reproduction in any Medium, provided the original work is properly cited.
} 
The Contribution of Muslims and Islamic Concepts: Rethinking and Establishing the Actual Origin of Concepts and Thought in Psychology

and believes in the obligation to conform to the 'Five Pillars', which are the confession of faith, the five daily prayers, payment of the poor-due, the fast of Ramadan, and performance of the Pilgrimage to Mecca by those physically and financially able to undertake it.” Islam believer may neglect one or more of the pillars (except the first) and still he is as a believer, but if he denies their necessity he has taken out of the community. (omer, 2015)

Cultural and intellectual globalization were imported from Muslim world in to west over 1000 years. Cipher, algebra, alcohol, admiral, amalgam, alcove, coffee, and more English words are derived from Arabic which showing the influence of Arabs on western culture.( Amber Haque, 2004)

If we consider the area of psychology we can also find early Muslim scholars who originated many psychological theories, thoughts and practices that is dominant today. But the written works are not readily available in English or not much translated in to English language. Quran and Sunnah which is in Arabic is the best psychological guide for mankind. (Amber Haque, 2004).

There are several Muslim scholars who contributed for psychology in earlier periods of time, these contributors followed the teachings of holy Quran and Sunnah of prophet Muhammad (pbuh) for the formation of Islamic concepts and theories.

\section{MUSLIM CONTRIBUTORS FOR PSYCHOLOGY}

Abu Yusuf Ya'qub ibn Ishaq Al-Kindi (ca. 800-870 CE)

Abu Yusuf Ya'qub ibn Ishaq Al-Kindi was the first self-identified philosopher in the Arabic tradition. His works are mainly focusing on philosophical topics, especially psychology. Extensive works in mathematics and sciences are also well known. For his works on astrology he was well known in both later Arabic and later tradition.

To prove that the soul is immaterial separate substances use Greek philosopher Aristotle's categories. In terms of Aristotle's theories of imagination, he gives an account of prophetic dreams for dreams and sleep. Many other works shed light on al-Kindi's works. Al kindi's psychological works are only existing works on ethics. (A Haque 2004).

On Sleep and Dreams (a treatise on dream interpretation), First Philosophy, and Eradication of Sorrow. In the latter, he described sorrow as "a spiritual (Nafsani) grief caused by loss of loved ones or personal belongings or by failure in obtaining what one lust after" and then added: "If causes of pain are discernible, the cures can be found." He suggested that "if we do not tolerate losing or dislike being deprived of what is dear to us, then we should seek after riches in the world of the intellect. 


\section{The Contribution of Muslims and Islamic Concepts: Rethinking and Establishing the Actual Origin of Concepts and Thought in Psychology}

\section{Al-Razi, Abu Bakr Muhammad ibn Zakariyya' (d. 925)}

Al-Razi's main focus on his career was as a physician, and In Baghdad which was the capital of the Islamic empire on the time, and the city of Rayy in north Iran, He directed hospitals in this both places. His writings on medicines were highly respected in the Universe. In this area, he earned lot of respects and widely spread his knowledge. His researches and writings continued in his old age. After his death students and assistances were surrounded in ah 313/ad925. He was known as Rhazes in Christian Europe

Al Razi believed that the cause for ${ }^{3}$ psychosomatic and ${ }^{4}$ organic disorders is the unexpected high emotional outburst as a quick curative effect. He mastered in psychosomatic medicine and prognosis and also anatomy. His work on "How to measure intelligence" is one of the great contributions for psychology, but unfortunately English translation could not be found. In 18th century in the west up he recognized as a authority, whoever write longest work in medicine (A Haque 2004).

According to Imam Razi (1149-1209), this جوهرis indeed the soul of a human being. In his opinion," نفس has a strong relationship with his heart and a person rules over his body (physical frame) by it. x 1. Self that tends to do evil نفس امارة 2. Self-reproaching conscience نفس لفامت 3. Self at peace نفس مطمئنت Conferring to the eminent National poet Allama Muhammad Iqbal Human personality has two aspects. One is physical and other is spiritual, and the human personality comprises with second one. Indeed, the human personality is the collective frame of attributes and characteristics. These characteristics or attributes differentiate the one human being to other. These attributes can be good or bad. It is why those two aspects of human personality (good or bad) form attributes. Holy Quran uses the term Nafs for the human personality. It is frequently used in it and represents complete picture of human personality (R.K. Qureshi, Q. H. Aziz ur Rehman 2016)

Razi's books provide definitions, symptoms, and treatment for problems related to mental illness in the $10^{\text {th }}$ century. During the time of fear of demonic possessions there are no any psychiatric hospitals in Europe. That time Razi was the director of two hospitals one is in Bagdad. His books El-Mansuri and Al-Hawi formed landmarks for the description of mental illness (Mohamed, WaelY, 2008)

\footnotetext{
${ }^{3}$ Psychosomatic related to certain organic disorders such as hypertension that are believed to be caused or aggravated by psychological factors, such as stress.

${ }^{4}$ Disorders involving physical lesion an organ or body part. An organic mental disorder is one involving disease, dysfunction or damage affecting the brain, arising from a primary brain disorder or injury, a disorder in another part of the body with secondary effects in the brain or the effects of a toxic substance.
}

(C) The International Journal of Indian Psychology, ISSN 2348-5396 (e)| ISSN: 2349-3429 (p) | 70 


\section{The Contribution of Muslims and Islamic Concepts: Rethinking and Establishing the Actual Origin of Concepts and Thought in Psychology}

\section{Abu Nasr Mohammad Ibn Al-Farakh (Al-Farabi) (870-950)}

Al Farabi was a Turkish and he also known as Alpharabius, Avenasser, or Abynazar. He contributes some works for ${ }^{5}$ Social Psychology, most renowned of which is his Model City. Al Farabi stated that without the aid of other individuals no one can achieve all the perfection by himself. It is inborn characteristics of every human being to join with other man or other men to perform. Every human has to stay with others or need to stay in the neighbourhood of others and link with them. According to Maslow (1970) in his hierarchy theory one step above the safety needs he explains about the social needs which include need to have friends, to beloved and appreciation and to belong. (Baron, 2012)

He made distinction between dream interpretation and the nature and cause of dream. He worked on the therapeutic effect of music and Meaning of the intellect. Like other philosopher, Al Farabi also gives explanations and review for the Greeks independent treatise, and rejection on the philosophers and theologians. Many for his works considers as the crown of his intellectual works. etc (Amber Haque 2004).

Here once more seeking your attention on the explanation that Al Farabi's social psychology and model city were the first work that talk about the social psychology. In psychology. He wrote that "an isolated individual could not achieve all the perfections by himself, without the aid of other individuals." He wrote that it is the "innate disposition of every man to join another human being or other men in the labour he ought to perform." He came to a conclusion that in order to "achieve what he can of that perfection; every man needs to stay in the neighbourhood of others and associate with them.(Mohammad Awais Tahir,2011)

\section{Abu Ali Al-Husayn B. Abd Allah Ibn Sina (980-1037)}

Ibn Sina, known as Avecenna. He was known basically as a philosopher and a physician, but he also contributed in the progression of all sciences in his period. The existence of mind, the body and mind relationship, perception, sensation, etc. wrote in his famous book Shifa (healing). He explains that whenever the mind wishes to move body, the body obeys .Here he saying that the mind influencing the body. Secondly the influence of mind on body is about emotion and the will. (Al Wahm al-Amil,Amber Haque 2004).

French philosopher Rene Decartes (1596-1650), suggested that mind and body are distinct entities and they interact through pineal gland, found deep within the brain; his view is known as dualism. Some other philosophers suggested that mind influence body and body influence mind. (Baron, 2012).

\footnotetext{
${ }^{5}$ Social psychology is the branch of psychology devoted to social behavior in all its forms, including altruism, attitudes, social compliance, conformity, obedience to authority, person perception, attribution group dynamics, group polarization, and non-verbal communication.
}

(C) The International Journal of Indian Psychology, ISSN 2348-5396 (e)| ISSN: 2349-3429 (p) | 71 


\section{The Contribution of Muslims and Islamic Concepts: Rethinking and Establishing the Actual Origin of Concepts and Thought in Psychology}

A good and noted description he gave for ${ }^{6}$ mood disorders. He linked the physical and psychological illness and described depression as a mood disorder with characteristics associated phobia.

In addition to the above-mentioned description he also pointed that anger is a factor for the progression of melancholia, which progression may lead to mania. He theorized that "happiness increases the breath, leading to uncontrolled increase in brain moisture and resulting in mental disorders” (Haque, 2004).

He discovered a condition that seems like ${ }^{7}$ schizophrenia and defined as junun Mufrit (severe madness) which having the characteristics symptoms like agitation and sleep disturbance, giving inappropriate answer to questions and occasional inability to speak. He said that in order to avoid the harm to them the patients have to be controlled. (Youssef and Youssef, 2002)

He separated human perceptions into the five external and five internal senses: (a) "senses communise or the seat of all senses that integrates sense data into precepts," (b) "the imaginative faculty which conserves the perceptual images," (c) "the sense of imagination, which acts upon these images by combining and separating them (by intellect in humans) and is therefore the seat of practical intellect," (d) "Wahm or instinct that perceives qualities like good and bad, love and hate, etc. and it forms the basis of one's character whether or not influenced by reason," (e)" intentions (ma'ni) that conserves in memory all these notions. He wrote about the potential intellect (within man) and active intellect (outside man) and that cognition cannot be mechanically produced but involves intuition at every stage.” (Amber Haque 2004).

For the treatment of illness which involving the emotion, he first recognized 'physiological psychological'. He developed a system for associating chances in the pulse rate with inner feeling. He was the innovator for psychophysiology and psychosomatic medicine. And this idea was in anticipation of the word-association test attributes to carl Jung. (Syed, 2002)

According Ibn sina, "ordinary human mind is like a mirror upon which a succession of ideas reflects from the active intellect. Before the acquisition of knowledge that emanates from the active intellect the mirror was rusty but when we think, the mirror is polished and it remains to direct it to the sun (active intellect) so that it could readily reflect light”. He also gave psychological explanations of certain somatic illnesses. He considered philosophizing as a way of making "the soul reach perfection". Ibn Sina always linked the physical and psychological

\footnotetext{
${ }^{6}$ Mood disorders. A class of mental disorders with disturbances of mood as the predominant feature such as depressive disorder

${ }^{7}$ Schizophrenia a major mental disorder characterized by positive symptoms such as delusions, hallucinations, disorganized speech, disorganized behaviour and catatonia. Negative symptoms such as affective flattening, alogia, or avolition, and marked deterioration in work, social relations, or self-care.
}

(C) The International Journal of Indian Psychology, ISSN 2348-5396 (e)| ISSN: 2349-3429 (p) | 72 


\section{The Contribution of Muslims and Islamic Concepts: Rethinking and Establishing the Actual Origin of Concepts and Thought in Psychology}

illnesses together Ibn Sina also wrote about symptoms and treatment of love sickness (Ishq), nightmare, epilepsy, and weak memory. (Amber Haque 2004).

\section{Abu Hamid Muhammad Al-Ghazali (1058-1111)}

Al-Ghazali discoursed the concept of the self and the causes of its misery and happiness. He described the self-using four terms:” Qalb (heart), Ruh (spirit), Nafs (soul) and 'Aql (intellect)”. He stated that "the self has an inherent yearning for an ideal, which it strives to realize and it is endowed with qualities to help realize it." He stated that the "self has motor and sensory motives for fulfilling its bodily needs". He wrote that the motor motives comprise of propensities and impulses, and further divided the propensities into two types: appetite and anger. He wrote that appetite urges hunger, thirst, and sexual craving, while anger takes the form of rage, indignation and revenge. He further wrote that impulse resides in the muscles, nerves, and tissues, and moves the organs to "fulfil the propensities." (Tahir,2011)

Al-Ghazali was one of the first to divide the sensory motives (apprehension) into five external senses (the classical senses of hearing, sight, smell, taste and touch) and five internal senses: common sense (Hiss Mushtarik) which synthesizes sensuous impressions carried to the brain while giving meaning to them; imagination (Takhayyul) which enables someone to retain mental images from experience; reflection (Tafakkur) which brings together relevant thoughts and associates or dissociates them as it considers fit but has no power to create anything new which is not already present in the mind; recollection (Tadhakkur) which remembers the outer form of objects in memory and recollects the meaning; and the memory (Hafiza) where impressions received through the senses are stored. (Mohammad Awais Tahir, 2011).

Ghazali's description of human nature cantered on discovering the "self, its ultimate purpose, and causes of its misery and happiness. He described the concept of self by four terms: Qalb, Ruh, Nafs, and Aql, which all signify a spiritual entity. He prefers the term Qalb for self in all his writings. Self has an inherent yearning for an ideal, which it strives to realize and it is endowed with qualities to help realize it. For fulfilling bodily needs the self has motor and sensory motives. Motor motives comprise of propensities and impulses. Propensities are of two types, appetite and anger. Appetite urges hunger, thirst and sexual craving. Anger takes form in rage, indignation, and revenge. Impulse resides in the muscles, nerves and tissues and moves the organs to fulfil the propensities. (Amber Haque 2004).

\section{Contribution of Islamic Concepts and Muslims for psychology}

Islamic medicine stressed the need for the understanding of human mental health. The first psychiatric hospitals and insane asylums were built in the Islamic world in Baghdad in 705, Fes (the third largest city in Morocco) in the 8th century, Cairo in 800, Damascus and Aleppo in 1270 (Syed, 2002). The most characteristic features of medieval Muslim psychotherapy were the 


\section{The Contribution of Muslims and Islamic Concepts: Rethinking and Establishing the Actual Origin of Concepts and Thought in Psychology}

use of clinical observations of mentally ill patients, which resulted in the provision of groundbreaking applications of moral treatment, baths, drug medication, music therapy and occupational therapy (Syed, 2002).

The concepts of mental health and mental hygiene were introduced by the Muslim physician Ahmed ibn Sahl al-Balkhi (850-934) (Table 1). His book, Sustenance for Body and Soul (in arabic: Masalih al-Abdan wa al-anfus), was the first book that discussed psychosomatic diseases with on emphasis on mind and body: "if the nafs (psyche) gets sick, the body may also find no joy in life with development of a physical illness" (Deuraseh and Abu Talib, 2005).

Ahmed ibn Sahl al-Balkhi was a pioneer of ${ }^{8}$ psychotherapy, psychophysiology and psychosomatic medicine. He was the first one who recognized that the body (fever, headache) and the soul (anger, anxiety and sadness) can be "healthy or sick or balanced or imbalanced". He recognized two types of depression: "one caused by known causes (physiological reasons) that can be treated through physical medicine; and the other caused by unknown reasons that can be treated psychologically” (Deuraseh and Abu Talib, 2005).

Najab ud-din Muhamed (10th century) made careful observations of mentally ill patients with detailed descriptions of a number of mental diseases including agitated depression, ${ }^{9}$ neurosis, periapism and sexual impotence (Nafkhae Malikholia), psychosis (Kutrib) and mania (DualKulb) (Syed, 2002; Youssef and Youssef, 1996).

Ibn al-Haytham is considered to be the founder of the experimental psychology and psychophysics (Khaleefa, 1999) with his distinguished book on the psychology of visual perception, Book of Optics (Steffens, 2006). Ibn al-Haytham was the first scientist to argue that vision occurs in the brain rather than the eyes in his Book of Optics (Edition III). Moreover, he pointed out that personal experience has an effect on what people see and how they see and that vision and perception are subjective feelings (Steffens, 2006).

Muslims applied modern therapeutic methods to the mentally ill right from there admission for treatment to discharge was customary to provide food and shelter to patients till recovery al khuzai-al Mawslli wrote about highly developed specimen of shadow play under the title, tayfal-khayal'fi Marifath Al-Zil' to add to the techniques which in many ways anticipated projective

\footnotetext{
${ }^{8}$ Psychotherapy is the treatment of mental disorders and allied problems by psychological methods such as behavior therapy, client centered therapy, cognitive behavior modification, and family therapy.

${ }^{9}$ Neurosis is an imprecise term for a relatively mild mental disorders with predominantly distressing symptoms and without loss of insight or reality testing, and without apparent organic etiology including anxiety neurosis, depersonalization neurosis, depressive neurosis, hysterical neurosis and obsessive compulsive neurosis.
}

(C) The International Journal of Indian Psychology, ISSN 2348-5396 (e)| ISSN: 2349-3429 (p) | 74 


\section{The Contribution of Muslims and Islamic Concepts: Rethinking and Establishing the Actual Origin of Concepts and Thought in Psychology}

doll play psychodrama (Graham,1967).Ghazali,Razi ,Ibn sina,Ibn miskwayh lay great stress on demand of whole man (Akbar,2006)

Avicenna often used psychological methods to treat his patients. One of his patients was a prince of Persia who had melancholia and suffered from the delusion that he was a cow, and who would low like a cow crying "Kill me so that a good stew may be made of my flesh" and would never eat anything. Avicenna was persuaded to take on the case and sent a message to the patient, asking him to be happy as the butcher was coming to slaughter him, and the sick man rejoiced. When Avicenna approached the prince with a knife in his hand, he asked "where is the cow so I may kill it?" The patient then lowed like a cow to indicate where he was. "By order of the butcher, the patient was also laid on the ground for slaughter." When Avicenna approached the patient pretending to slaughter him, he said, "the cow is too lean and not ready to be killed. He must be fed properly and I will kill it when it becomes healthy and fat." The patient was then offered food which he ate eagerly and gradually "gained strength, got rid of his delusion, and was completely cured" (Haque, 2004).

The result of study did by Moghadam \& Moradi in 2011, The Holy Quran in four verses and infallible imams in several hadiths have prohibited alcohol consumption for humans. On the other hand, it leads to many socioeconomic and mental damages and results in detriments on the Central and Peripheral Nervous System. Cardiovascular System, Liver, Bone, Pancreas, Skin and Respiratory System are such organs and tissues in which bear loads of heavy irreversible injuries from alcohol consumption. Harmful effects of alcohol on fetus and causing different malignancy in several tissues are from other fatal effects which eventually lead to death.

Ethanol affects nearly all brain systems and causes rapid adaptation, changes in neurochemical pathways and these alterations often are associated with morbidity (Bahi, 2012). Alcohol disturbs the balance between excitatory and inhibitory events in the brain, resulting in anxiolysis, ataxia, and sedation (Dar, 2011). Ethanol probably produces its effects by changing the function of a number of ligand-gated and voltage-gated ion channels and GPCR (G-protein coupled receptors) systems.

Heavy alcohol digestion can cause hypertension with raises in diastolic and systolic blood pressure (Taylor et al., 2009). Chronic heavy drinking develops a more permanent cognitive deficit that referred to as alcoholic dementia (Alfonso-Loeches and Guerri, 2011). WernickeKorsakoff syndromes causes by thiamine depletion following heavy ethanol digestion. Atrophy of the cerebellar vermis and a peripheral neuropathy are the others neurological syndromes associated with chronic heavy use of alcohol (Matsushita, 2014). 
The Contribution of Muslims and Islamic Concepts: Rethinking and Establishing the Actual Origin of Concepts and Thought in Psychology

God introduced wine as a harmful substance and expressed its disadvantages is more than benefits more than 1400 years ago in holy Quran. So that usage of wine is great sin in Islam. However, until 2 centuries ago, complications of alcohol usage were not known. It has been revealed that this substance has numerous dangerous effects. Irreversible effects such as changing in neurotransmission pathways in brain, cardiomyopathy, and disturbance in mental balances have been proven (Saunders et al., 1993).

\section{CONCLUSION}

The dedicated life of the earlier Muslim scholars contributes great concepts, practices and theories to psychology. Those contributions play a good role to develop psychology for the mentally ill people as a blessed finding for the future brightness of the field of psychology. The actual origin of the concepts and theories are contributed and originated from the Islamic concepts but those great dedications are not exploring in academic article or books to spread such an extraordinary thoughts of scholars.

\section{Acknowledgments}

The author appreciates all those who participated in the study and helped to facilitate the research process.

Conflict of Interests: The author declared no conflict of interests.

\section{REFERENCES}

A, Abed and L, Safaeian (2012). "Advantages and Disadvantages of Alcoholic Beverages; What Is the Opinion of the Holy Quran?”. Retrieved from: https://www.researchgate.net/profile/Leila_Safaeian/publication/234040351_Advantages _and_Disadvantages_of_Alcoholic_Beverages_What_Is_the_Opinion_of_the_Holy_Qur an/links/09e4150e7b6af333ef000000.pdf

A, Haque (2004). "Psychology from Islamic Perspective: Contributions of Early Muslim Scholars and Challenges to Contemporary Muslim Psychologists". Retried from: http://www.jstor.org/stable/pdf/27512819.pdf

G, Frank (2004). "Al-Ghazali's Unspeakable Doctrine of the Soul: Unveiling the Esoteric Psychology and Eschatology of the Ihya" retrieved from: http://go.galegroup.com/ps/anonymous?id=GALE\%7CA131969206\&sid=googleScholar $\& \mathrm{v}=2.1 \& \mathrm{it}=\mathrm{r} \&$ linkaccess $=$ fulltext\&issn $=00030279 \& \mathrm{p}=\mathrm{AONE} \& \mathrm{sw}=\mathrm{w} \&$ authCount $=1 \&$ is AnonymousEntry=true

M Hassan Ghosian, M Moradi (2011). "Effects of Alcohol Consumption on Human Health from the Perspective of Holy Quran and Modern Medicine". retrieved from: file://C:/Users/Ajmal/Downloads/8162.pdf

M, Ansari. "Psychology of Mohammad". Online book Retrieved from: 
The Contribution of Muslims and Islamic Concepts: Rethinking and Establishing the Actual Origin of Concepts and Thought in Psychology

http://bibotu.com/books/Truth\%20About\%20Islam/PshychologyOfMohammad.pdf.

W, M Mohamed (2012). "Arab and Muslim Contributions to Modern Neuroscience". retrieved from: file:///D:/ZTORAGE\%20DELL/My\%20Researches/isalm\%20and\%20psy/Araband-Muslim-Contributions-to-Modern-Neuroscience.pdf

How to cite this article: Majeed A, Jabir K (2017), The Contribution of Muslims and Islamic Concepts: Rethinking and Establishing the Actual Origin of Concepts and Thought in Psychology, International Journal of Indian Psychology, Volume 4, Issue 2, No. 96, ISSN:23485396 (e), ISSN:2349-3429 (p), DIP:18.01.187/20170402, ISBN:978-1-365-84232-0 